\title{
Quantitative analysis of the impact of short-time high hydrostatic pressure on bone tumor-associated proteases
}

\author{
PETER DIEHL $^{1,2}$, JOHANNES SCHAUWECKER ${ }^{2}$, KAY EICHELBERG $^{2}$, \\ HANS GOLLWITZER $^{4}$, URSULA MAGDOLEN ${ }^{2}$, LUDGER GERDESMEYER ${ }^{2}$, \\ WOLFRAM MITTELMEIER $^{1}$ and MANFRED SCHMITT ${ }^{3}$
}

\author{
${ }^{1}$ Department of Orthopedic Surgery, University of Rostock, Rostock; ${ }^{2}$ Department of Orthopedic Surgery \\ and ${ }^{3}$ Clinical Research Unit of the Department of Obstetrics and Gynecology, Technical \\ University of Munich, Munich; ${ }^{4}$ Trauma Center Murnau, Murnau, Germany
}

Received November 9, 2006; Accepted December 14, 2006

\begin{abstract}
In orthopedic surgery, sterilization of bone used for reconstruction of osteoarticular defects caused by malignant tumors is carried out in various ways. At present, to devitalize tumor-bearing osteochondral segments, extracorporeal irradiation or autoclaving is mainly used, although both methods have substantial disadvantages, leading to a significant loss of biomechanical and biological integrity of the bone. As an alternative approach, a new technology to achieve bone sterilization, the high hydrostatic pressure (HHP) treatment of bone, has been suggested, which is currently being preclinically tested. This novel technique leads to the inactivation of tumor cells without impairing biomechanical properties of the bone, cartilage, or tendons. HHP may not only exert an effect on tumor and normal cells present in the bone but also on tumor-associated proteases released by these cells, which are conductive to tumor bone turnover. In order to investigate this, proteolytic key enzymes, e.g. MMP-9, uPA, t-PA, plasmin, trypsin, and thrombin were subjected to HHP $\leq 600 \mathrm{MPa}$. Thereafter, compared to the non-pressurized enzymes, the proteolytic activity of the pressurized enzymes was determined. The proteases studied showed varying degrees of susceptibility to HHP, depending on the pressure level applied. The latent activity of the inactive zymogens prothrombin, plasminogen, and pro-uPA, in addition to the proteolytically active forms of plasmin, thrombin, HMW-uPA, and trypsin were minimally affected by $\mathrm{HHP}\left(10 \mathrm{~min}, 20^{\circ} \mathrm{C}, 600 \mathrm{MPa}\right)$ with a reduction of activity up to $13 \%$ only, whereas t-PA was significantly impaired by a reduction of activity of $30 \%$. In contrast, for
\end{abstract}

Correspondence to: Dr Peter Diehl, Orthopaedische Klinik und Poliklinik der Technischen Universitaet Muenchen, Ismaninger Str. 22, D-81675 Munich, Germany

E-mail: p.diehl@1rz.tum.de

Key words: high hydrostatic pressure, bone, tumor, proteases pressurized pro-MMP-9 $\left(10 \mathrm{~min}, 5^{\circ} \mathrm{C}, 400 \mathrm{MPa}\right)$ a 3 -fold increase in enzymatic activity was observed after activation compared to non-pressurized pro-MMP-9. No activation of pro-MMP-9 due to HHP was observed. These data encourage further exploration of the potential of HHP to sterilize tumoraffected bone segments prior to reimplantation. During this treatment tumor cells are irreversibly impaired, while HHP treatment of proteases may not exert any significant autolytic effect on bone tissue.

\section{Introduction}

Reconstruction of bone defects caused by malignant tumors can be achieved by several approaches. For instance, extracorporeal irradiation or autoclaving of the affected bone segment before reimplantation is an alternative approach to the use of synthetic limb reconstruction. Yet, one has to assure that all of the tumor cells are inactivated prior to reimplantation in order to avoid disease recurrence. Nevertheless, irradiation or autoclaving of osteochondral segments and tendons may cause drastic alteration of the biomechanical and biological properties of the treated tissue, a major concern regarding this type of inactivation approach. Consequently, there is an urgent clinical need for alternative methods of bone treatment prior to retransplantation leaving the osteochondral segments intact. Therefore, it is advantageous to the patient to develop an adequate procedure that would allow complete tumor cell inactivation of a bone segment but, at the same time, would not impair its biomechanical and biological properties. As a new technology currently undergoing pre-clinical testing, the administration of short-term high hydrostatic pressure (HHP) to the resected bone segment immediately after surgery would offer an alternative to the present method of tumor-affected bone treatment.

The effect of HHP on the viability of human tumor cells and human tumor-afflicted bone specimens has been investigated (1-4). We observed that due to excessive hydrostatic pressure at $350 \mathrm{MPa}$, normal and tumor cells were irreversibly damaged and nonviable while the biomechanical properties of bone, cartilage, and tendons remained unimpaired, even at pressures as high as $600 \mathrm{MPa}$ 
(5-7). Notably, no significant changes in the adhesive or growth-promoting properties of the extracellular matrix (ECM) proteins fibronectin, vitronectin, and collagen-I, were observed after this treatment (8). Little is known, however, about the effects of HHP on tissue-remodelling serine proteases and matrix metalloproteinases, some of which are also overexpressed in malignant tissues or bone turnover $(9,10)$. With regard to the involvement of serine proteases in tumor bone degradation, the serine proteases urokinase-type plasminogen activator (uPA) and tissue-type plasminogen activator (t-PA) are key enzymes catalyzing the conversion of the proenzyme plasminogen to its proteolytic active form plasmin, which may directly attach and degrade ECM proteins of the bone matrix. In contrast, the serine protease thrombin may cleave and thereby inactivate pro-uPA, in this way rendering an enzymatically inactive form of uPA (11). MMP-9, a key matrix metalloproteinase conductive in bone resorption processes (12), is present in the developing and remodelling bone, and also in human osteosarcomas $(13,14)$. Similar to plasmin and uPA, MMP-9 is secreted as an inactive zymogen and then further activated by proteolytic cleavage before its degradative action on ECM components. Furthermore, via interaction with protease-activated receptors (PAR), thrombin may induce bone cell activation, following increased release of pro-MMP-9 (15).

Although beneficial to tumor cell inactivation and biomechanical properties, the investigated proteases might be activated after HHP treatment of the resected human bone tumor, eventually leading to autolytic bone resorption. Therefore, in the present study, we analyzed the effects of HHP $\leq 600 \mathrm{MPa}$ on the enzymatic properties of tissueassociated proteases known to be involved in human malignant bone turnover.

\section{Materials and methods}

High hydrostatic pressure (HHP) treatment of proteases and their proenzyme forms. Lyophilized pro-uPA (Grünenthal GmbH, Aachen, Germany) and HMW-uPA (Curasan, Kleinostheim, Germany) were resolved in phosphatebuffered saline (PBS), pH 7.4 (pro-uPA, $10 \mathrm{mg} / \mathrm{ml}$; HMWuPA, 100,000 U/ml), aliquoted and then stored at $-20^{\circ} \mathrm{C}$. Before pressure treatment, pro-uPA and HMW-uPa were diluted to a concentration of $60 \mu \mathrm{g} / \mathrm{ml}$ and $4,000 \mathrm{U} / \mathrm{ml}$ in $100 \mathrm{mM}$ Tris-HCl plus $0.5 \%$ Tween-20 (v/v), pH 7.5.

Lyophilized prothrombin (Haemochrom Diagnostica GmbH, Essen, Germany) and thrombin (Sigma-Aldrich, Steinheim, Germany) were resolved in PBS, $\mathrm{pH} 7.4$, (prothrombin, $1 \mathrm{mg} / \mathrm{ml}$; thrombin, $1000 \mathrm{U} / \mathrm{ml}$ ), and then stored at $-20^{\circ} \mathrm{C}$. Before pressure treatment, prothrombin and thrombin were diluted to a concentration of $3 \mu \mathrm{g} / \mathrm{ml}$ and $6 \mathrm{U} / \mathrm{ml}$, in $20 \mathrm{mM}$ Tris- $\mathrm{HCl}, 0.1 \mathrm{M} \mathrm{NaCl}, \mathrm{pH} \mathrm{7.4}$, and $100 \mathrm{mM}$ Tris$\mathrm{HCl}$ plus $0.5 \%$ Tween-20 (v/v) at $\mathrm{pH} 7.5$, respectively.

Plasminogen (Roche Diagnostics, Penzberg, Germany), plasmin (American Diagnostica, Pfungstadt, Germany), t-PA (Haemochrom Diagnostica), and trypsin (Roche Diagnostics) were dissolved in PBS, pH 7.4 (plasminogen, $10 \mathrm{U} / \mathrm{ml}$; plasmin, $2 \mathrm{mg} / \mathrm{ml}$; t-PA, $50000 \mathrm{U} / \mathrm{ml}$; and trypsin, $1 \mathrm{mg} / \mathrm{ml}$ ), aliquoted and then stored at $-20^{\circ} \mathrm{C}$. Before pressure treatment, plasminogen and plasmin were diluted to a concentration of
$10 \mathrm{U} / \mathrm{ml}$ and $10 \mu \mathrm{g} / \mathrm{ml}$, respectively, in $100 \mathrm{mM}$ Tris- $\mathrm{HCl}$ plus $0.5 \%$ Tween-20 (v/v), $\mathrm{pH} 7.5$; t-PA was diluted to a concentration of $320 \mathrm{U} / \mathrm{ml}$ in $100 \mathrm{mM}$ Tris- $\mathrm{HCl} 0.5 \%$ plus Tween-20 (v/v), pH 8.4; and trypsin was diluted to a concentration of $100 \mathrm{U} / \mathrm{ml}$ in $100 \mathrm{mM}$ Tris- $\mathrm{HCl}$ plus $0.5 \%$ Tween-20 (v/v), pH 7.5.

Recombinant pro-MMP-9, stored at $-20^{\circ} \mathrm{C}$, was obtained from Oncogene (Boston, MA, USA). pro-MMP-9, purified from human granulocytes, was kindly provided by $\mathrm{H}$. Tschesche, University of Bielefeld, Germany. Recombinant pro-MMP-9 and native pro-MMP-9 were dissolved in the buffer solution described by Verheijen et al (16). The solutions $(100 \mathrm{ng} / \mathrm{ml})$ were stored at $-20^{\circ} \mathrm{C}$. Before pressure treatment, dilutions of $100 \mathrm{ng} / \mathrm{ml}$ of the recombinant and $30 \mathrm{ng} / \mathrm{ml}$ of the native pro-MMP-9 were prepared.

The vials to be used for HHP-treatment were tightly sealed with Parafilm ${ }^{\circledR}$ (American National Can, Joplin, MO, USA), vacuum-packed, and then placed into the water-filled central cavity of a custom-made high pressure device (Record $\mathrm{GmbH}$, Koenigsee, Germany) (8). The vials containing the serine proteases were exposed to HHP values of 300 and 600 $\mathrm{MPa}$, at room temperature. The vials containing the enzyme solutions were exposed to HHP values of 200 and $400 \mathrm{MPa}$, at $5^{\circ} \mathrm{C}$ to avoid autoactivation. The defined HHP values were reached within a few seconds, and afterward the vials were kept under defined pressure for $10 \mathrm{~min}$ and then relaxed to atmospheric pressure within a few sec.

For in vitro activation of pro-MMP-9, $1 \mathrm{mM}$ of the zymogen activator p-aminophenylmercuric acetate (APMA) (GE Healthcare, Freiburg, Germany) was added after or before pressure treatment.

Activity assay for determination of the effect of HHP treatment. Chromogenic assays were performed in 96-well microtiter plates (Greiner, Frickenhausen, Germany).

pro-uPA and $H M W-u P A$. pro-uPA and its activated form, HMW-uPA, were diluted to $60 \mu \mathrm{g} / \mathrm{ml}$ and $1000 \mathrm{U} / \mathrm{ml}$, respectively, in $0.1 \mathrm{M}$ Tris- $\mathrm{HCl}$ plus $0.5 \%$ Tween-20 (v/v), $\mathrm{pH} 7.5$, in a total volume of $80 \mu \mathrm{l}$ for pro-uPA and $95 \mu \mathrm{l}$ for HMW-uPA. Before addition of the substrate solution, prouPA was incubated with $5 \mathrm{ml}$ of $1 \mathrm{mg} / \mathrm{ml}$ plasmin at room temperature and then $25 \mu 1$ of the chromogenic substrate S2444 (2 mM; Haemochrom Diagnostica) was added to both solutions. Absorption values $(405 \mathrm{~nm})$ were measured at $37^{\circ} \mathrm{C}$ after 4,8 , and $12 \mathrm{~min}$ for pro-uPA and after 20,40, and 60 min for HMW-uPA.

Prothrombin and thrombin. Prothrombin and thrombin were each diluted in $20 \mathrm{mM}$ Tris- $\mathrm{HCl}, 0.1 \mathrm{M} \mathrm{NaCl}, \mathrm{pH} 7.4$; prothrombin was adjusted to $80 \mu \mathrm{l}(0.375 \mu \mathrm{g} / \mathrm{ml})$ and thrombin to $1.5 \mathrm{U}$ in $95 \mu 1$. For activation, prothrombin was incubated with $0.6 \mathrm{U} / \mathrm{ml}$ ecarin (total volume of $20 \mu \mathrm{l}$ ) (Sigma, Taufkirchen, Germany) at room temperature and then $25 \mu 1$ of the chromogenic substrate S-2238 (prothrombin, $3 \mathrm{mM}$; thrombin, $2 \mathrm{mM}$; Haemochrom Diagnostica) was added. Immediately after incubation, the absorption was measured at $405 \mathrm{~nm}\left(37^{\circ} \mathrm{C}\right)$ after 4,12 , and $20 \mathrm{~min}$ for prothrombin and 10, 20, and $40 \mathrm{~min}$ for thrombin.

Plasminogen and plasmin. Plasminogen $(60 \mu 1$ of $0.025 \mathrm{U} /$ $\mathrm{ml})$ and plasmin $(95 \mu \mathrm{l}$ of $1.25 \mu \mathrm{g} / \mathrm{ml})$ were diluted in $0.1 \mathrm{mM}$ Tris- $\mathrm{HCl}$ plus $0.5 \%$ Tween-20 (v/v), pH 7.5. 
Streptokinase (30 $\mu 1)$ (4000 IE) (Sigma) was added at room temperature to convert plasminogen to plasmin and then $30 \mu \mathrm{l}$ of the chromogenic substrate S-2403 (3 mM; Haemochrom Diagnostica) was added for plasmin, for plasminogen and $25 \mu \mathrm{l}$ of chromogenic substrate S-2251 (4 mM; Haemochrom Diagnostica,) for plasmin, were added. Immediately after incubation, the absorption was measured $(405 \mathrm{~nm})$ at $37^{\circ} \mathrm{C}$ after 10, 20, and $40 \mathrm{~min}$ for plasminogen, and at 20,40, and $60 \mathrm{~min}$ for plasmin.

$t$ - $P A$. t-PA was adjusted to $80 \mathrm{U} / \mathrm{ml}$ in $95 \mu \mathrm{l}$ of $0.1 \mathrm{M}$ Tris- $\mathrm{HCl}$ plus Tween-20 (v/v), $\mathrm{pH} 8.4$, and then $25 \mu \mathrm{l}$ of chromogenic substrate S-2288 (5 mM; Haemochrom Diagnostica) was added at room temperature. Absorption at $405 \mathrm{~nm}$ was measured $\left(37^{\circ} \mathrm{C}\right)$ after 2,4 , and $8 \mathrm{~h}$.

Trypsin. Trypsin was adjusted to $12.5 \mathrm{U} / \mathrm{ml}$ in $95 \mu \mathrm{l}$ of $0.1 \mathrm{M}$ Tris $-\mathrm{HCl}$ plus $0.5 \%$ Tween-20 (v/v), $\mathrm{pH} 7.5$, and then $25 \mu 1$ of chromogenic substrate S-2266 (2 mM; Haemochrom, Diagnostica) was added at room temperature. Absorption $(405 \mathrm{~nm})$ was measured at $37^{\circ} \mathrm{C}$ after 2,4 , and $8 \mathrm{~h}$.

Pro-MMP-9 and MMP-9. The assay was performed according to the protocol of Verheijen et al (16) (Biotrak MMP-9 activity assay system, GE Healthcare). Briefly, this assay was designed so that the immobilized antibodies to MMP-9 interact with pro-MMP-9 and MMP-9 present in the test fluid. For MMP-9, enzymatically active MMP-9 was then measured in the plate after the addition of modified recombinant urokinase which was cleaved and thereby activated by MMP-9. Subsequently, to visualize MMP-9 activity a substrate for urokinase was added. Similarly, proMMP-9 can be captured by the antibody, but then it must be converted into its enzymatically active state by APMA, prior to the addition of urokinase and the urokinase substrate. Absorption was measured at $405 \mathrm{~nm}$.

Gel zymography for determination of (pro-)MMP-9 activity. SDS-PAGE was carried out with pro-MMP-9 before and after HHP, to determine the effect of this treatment on this latent form of MMP-9. Aliquots of $18 \mu 1$ of recombinant MMP-9 (64 ng/ml) and native MMP-9 (200 ng/ml) were used for each zymogram. The samples were mixed 1:4 with zymogram sample buffer consisting of $250 \mathrm{mM}$ Tris- $\mathrm{HCl}$, $275 \mathrm{mM}$ sodium dodecylsulfate (SDS), $40 \%$ glycerol, and $0.2 \%$ bromophenol blue ( $\mathrm{pH} 6.8)$. Samples were placed into the wells of a gelatin-SDS-gel (40\% acrylamide, 10\% SDS). Separation of the samples was carried out under a constant current of $20 \mathrm{~mA}$ for $2.5 \mathrm{~h}$ under non-reducing conditions using a minigel slab device (BioRad, Munich, Germany). After electrophoresis, SDS was removed by emersing the gel in a buffer consisting of $50 \mathrm{mM}$ Tris and $2.5 \%$ Triton X-100 (pH 7.5) for $30 \mathrm{~min}$. Thereafter the zymograms were incubated for $19 \mathrm{~h}\left(37^{\circ} \mathrm{C}\right)$ in $50 \mathrm{mM}$ Tris- $\mathrm{HCl}, \mathrm{pH} 7.5$. Following three washing steps with distilled $\mathrm{H}_{2} \mathrm{O}$, the gels were stained for $2 \mathrm{~h}$ in Coomassie blue solution. Unstained areas, corresponding to zones of gelatin digestion, became visible after destaining in $10 \%$ isopropanol/10\% acetic acid.

For control purposes, blocking of MMP-9 was performed with ethylendiaminotetraacetic acid (EDTA) and phenylmethylsulfonylfluoride (PMSF). While EDTA inhibits metalloproteinases, PMSF does not because it is an inhibitor of serine and cysteine proteinases $(17,18)$.

\section{Results and Discussion}

At present, reconstruction of tumor cell bearing osteochondral segments is mainly accomplished by two methods: extracorporeal irradiation or autoclaving, with subsequent reimplantation of the treated segment. Both methods, however, suffer from major drawbacks, e.g. loss of biomechanical and biological properties (19-24). Accordingly, there is an urgent clinical need for alternative methods of treating tumor-afflicted bone segments prior to reimplantation. HHP is a new technology, undergoing preclinical testing in order to explore whether it is suited for extracorporeal inactivation of tumor cells in bone, while leaving the biomechanical properties unchanged.

In previous studies on eukaryotic cells, including tumor cells, and on human tumor-afflicted bone specimens, we have provided evidence that malignant tumor cells were irreversibly damaged after HHP-treatment at pressure levels of $350 \mathrm{MPa}$, while the biomechanical properties of bone, tendon, and cartilage were unaffected, even at exposures as high as $600 \mathrm{MPa}(5-7)$.

Also, significant changes in the adhesive or growthpromoting properties of the extracellular matrix proteins fibronectin, vitronectin, or collagen-I were not observed (8).

HHP may exert its effect not only on the tumor cell or extracellular matrix architecture, but also on cellular constituents such as proteases, which are known to be involved in bone turnover, in cellular motility and cell invasion $(25,26)$. Therefore, we tested the possibility whether HHP affects the proteolytic activity of certain proteases. Matrix metalloproteinase-9 (MMP-9) and various serine proteases which are known to be present in normal and malignant tissues, including the bone were tested $(9,10,13)$. Until now, no information was available on the effect of HHP on proteases involved in tissue or extracellular matrix turnover. In order to investigate this, pro-uPA, its activated form HMW-uPA, plasminogen, its activated form plasmin, prothrombin, its activated form thrombin, as well as t-PA and for comparison trypsin in buffer solution were subjected to pressure values $\leq 600 \mathrm{MPa}$. Thereafter, the enzymatic activity of treated or untreated enzymes was measured by turnover of synthetic chromogenic substrates. HHP exerted no significant effects on the investigated serine proteases at $300 \mathrm{MPa}$ $\left(20^{\circ} \mathrm{C}, 10 \mathrm{~min}\right)$. At $600 \mathrm{MPa}$, except t-PA, all of the investigated serine proteases [(pro)thrombin, plasmin(ogen), (pro-)uPA, and trypsin)] were minimally affected (Fig. 1) by short time exposure of $10 \mathrm{~min}$ at $20^{\circ} \mathrm{C}$ in buffer solution. Under these conditions, normal and tumor cells were irreversibly damaged by HHP. Similar findings were reported for other enzymes tested, such as acid phosphatase for which a slight decrease of activity of $\sim 4 \%$ after hydrostatic pressure treatment (600 MPa, $5 \mathrm{~min}, 10^{\circ} \mathrm{C}$ ) (27) was demonstrated. However, in contrast to our data, Lima et al observed a linear decline in human $\alpha$-thrombin activity by $55 \%$ at $270 \mathrm{MPa}\left(25^{\circ} \mathrm{C}, 10 \mathrm{~min}\right)$ (28) also using the synthetic substrate S-2238 (3 mM). Ruan et al described that the proteolytic activity of bovine pancreas trypsin was impaired when pressure values exceeded $600 \mathrm{MPa}$ $\left(20^{\circ} \mathrm{C}\right)(29)$. To note, it was found that the enzymatic activity of trypsin was completely lost when the temperature was reduced to $0^{\circ} \mathrm{C}$ even at a lower HHP (350 MPa) (29). 

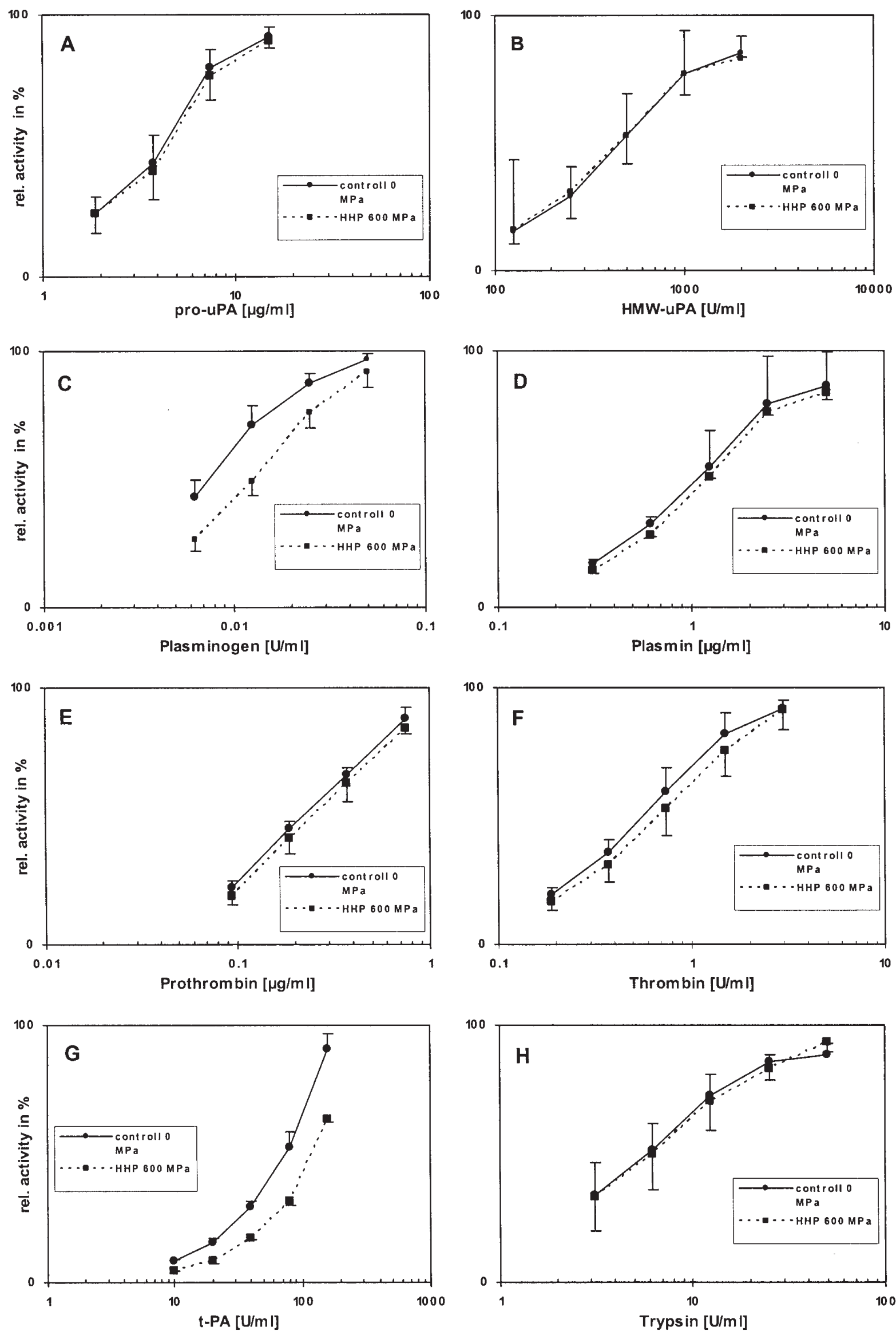

Figure 1. Enzymatic activity determined for untreated and HHP-treated serine proteases $\left(600 \mathrm{MPa}, 10 \mathrm{~min}, 20^{\circ} \mathrm{C}\right)$. The relative activity of enzymes was measured by photometric absorption. (A) Enzymatic activity of pro-uPA $(10 \mathrm{mg} / \mathrm{ml})$ after activation with plasmin $(1 \mathrm{mg} / \mathrm{ml}) ;(B) \mathrm{HMW}-\mathrm{uPA}(100,000 \mathrm{U} / \mathrm{ml})$; (C) plasminogen $(10 \mathrm{U} / \mathrm{ml})$ after activation with streptokinase (4,000 IE); (D) plasmin $(50,000 \mathrm{U} / \mathrm{ml})$; (E) prothrombin $(1 \mathrm{mg} / \mathrm{ml})$ after activation with ecarin $(0.6 \mathrm{U} / \mathrm{ml}) ;(\mathrm{F})$ thrombin $(1,000 \mathrm{U} / \mathrm{ml}) ;(\mathrm{G}) \mathrm{t}-\mathrm{PA}(320 \mathrm{U} / \mathrm{ml})$; and $(\mathrm{H})$ trypsin $(100 \mathrm{U} / \mathrm{ml})$. Depicted values are means and the standard deviation of at least three independent experiments. 

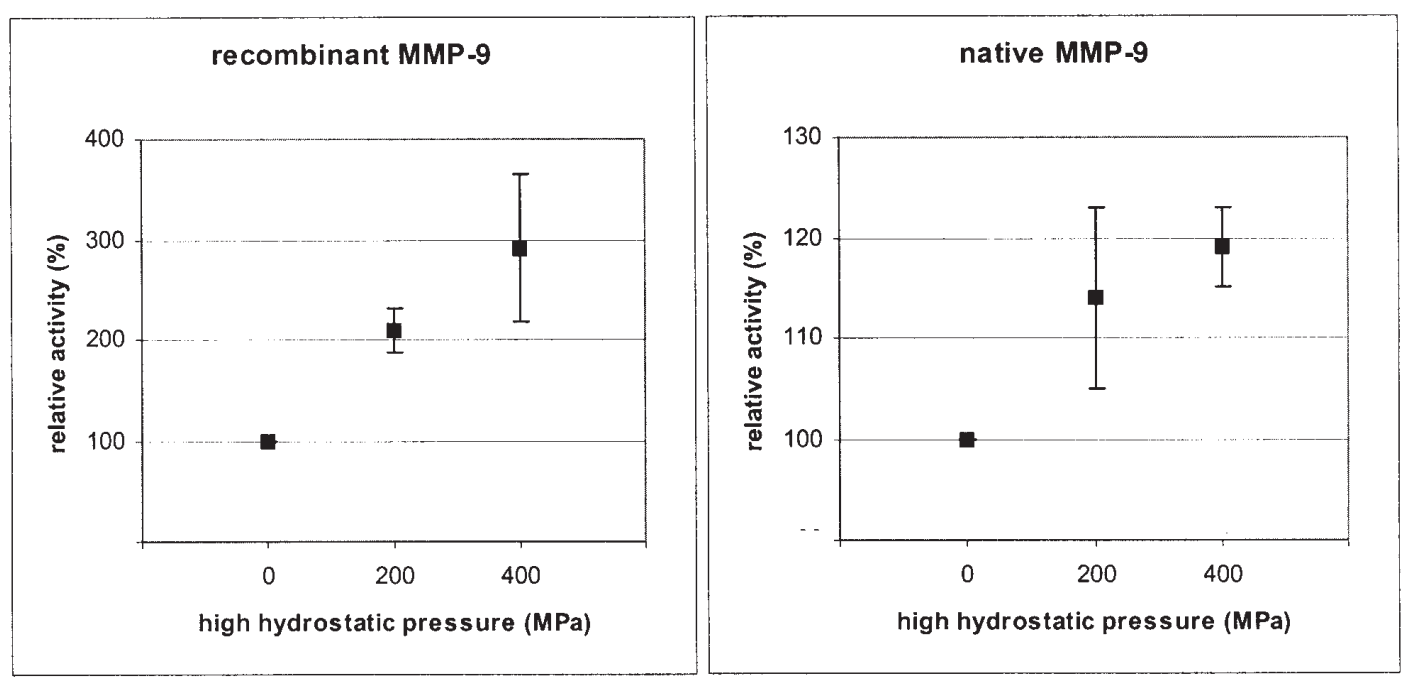

Figure 2. Enzymatic activity of native and recombinant pro-MMP-9 after HHP treatment $\left(0,200\right.$, and $\left.400 \mathrm{MPa}, 10 \mathrm{~min}, 5^{\circ} \mathrm{C}\right)$ followed by activation with APMA. Activity of untreated control group (0 MPa) has been set to $100 \%$.

Unfortunately, it was not documented in the study by Ruan et al for how long the samples had been treated with HHP. On the other hand, as shown in the present study (Fig. 1), the proteolytic activity of t-PA was reduced by $\sim 30 \%$ when exposed to HHP of $600 \mathrm{MPa}\left(20^{\circ} \mathrm{C}, 10 \mathrm{~min}\right)$.

When recombinant pro-MMP-9 was pressurized (10 min, $\left.5^{\circ} \mathrm{C}, 400 \mathrm{MPa}\right)$, and then, after activation with APMA, subjected to an MMP-9/urokinase activity assay, a significant increase to 3-fold in enzymatic activity of MMP-9 was observed (Fig. 2). Notably, with pro-MMP-9 purified from human leukocytes, only a slight increase in enzymatic activity to $20 \%$ was seen after HHP and following APMA activation (Fig. 2). The SDS-PAGE zymography results for MMP-9 show two prominent gelatinolytic bands corresponding to pro-MMP-9 (92 kDa) and to active MMP-9 (84 kDa) (Fig. 3). Autoactivation of pro-MMP-9 due to HHP treatment depicted as a distinct gelatinolytic band at $84 \mathrm{kDa}$ was not observed (Fig. 3). Yet, after HHP treatment of $400 \mathrm{MPa}$, a slight additional band appeared at $70 \mathrm{kDa}$ indicating degradation but not a complete loss of activity (Fig. 3).

Similar findings as ours for pro-MMP-9 were reported for the aspartyl protease cathepsin D subjected to 400 and $500 \mathrm{MPa}$, respectively $\left(10^{\circ} \mathrm{C}, 2.5 \mathrm{~min}\right)$. At $400 \mathrm{MPa}$ an increase in activity was observed, whereas the proteolytic activity of cathepsin D showed a marked decrease at $500 \mathrm{MPa}$ (27). These findings are in line with data by others, investigating the effect of HHP on cysteine protease cathepsin B, L and H. All enzymes lost their enzymatic activity at elevated pressure values, but the degree of loss was enzyme-dependent (30).

The results of this study demonstrate resistance of serine proteases UPA, thrombin, and plasmin, including their zymogen forms, and that of trypsin to HHP as high as $600 \mathrm{MPa}$. Interestingly, t-PA, the tissue-type plasminogen activator activity was slightly reduced at this pressure value. Our results are in accordance with literature results, demonstrating that the effects of HHP on the structure and function of a certain protein cannot be predicted. Therefore, susceptibility of proteases to HHP-induced molecular changes may vary also, depending on the extent and duration

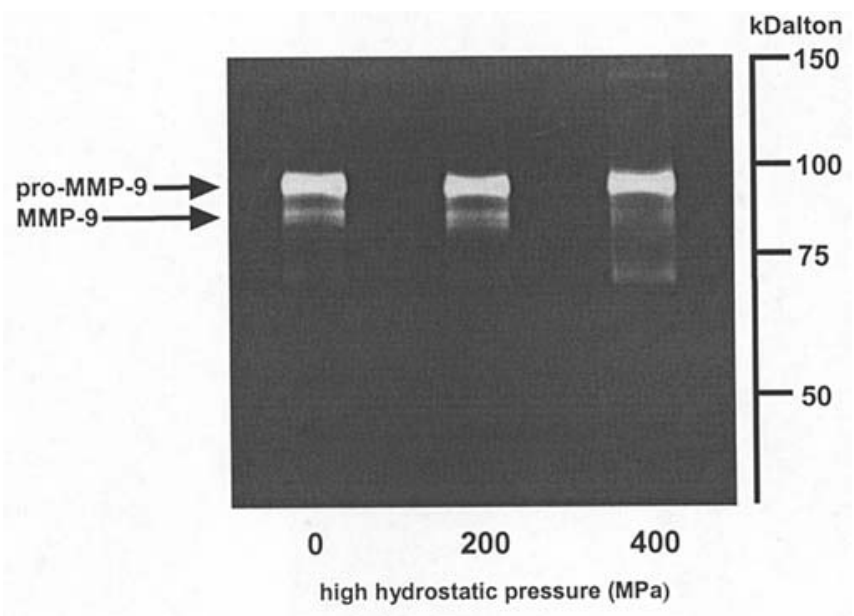

Figure 3. Zymography of MMP-9 after high hydrostatic pressure treatment. Two gelatinolytic bands are detected at $92 \mathrm{kDa}$ (pro MMP-9) and $84 \mathrm{kDa}$ (active MMP-9). At $400 \mathrm{MPa}$ a slight additional band appears at $70 \mathrm{kDa}$.

of pressure, temperature, buffer composition, and the molecular characteristics of a protein (31-33). This assumption is supported by the fact that various enzymes are deactivated by HHP while others are not affected by this treatment, or even show an increase in biological activity (31-33). As a result, some monomeric molecules are not destroyed by HHP, even at pressures as high as 1,000 $\mathrm{MPa}$ (34), while some multimeric proteins disintegrate at HHP $<300 \mathrm{MPa}$ (31). The variation seen between different enzymes is probably due to differences in molecular structures and the resulting modifications after HHP treatment $(34,35)$. Conformational changes of proteins induced by HHP may result from changing the interaction of water molecules with the target molecules, eventually leading to alterations of the intramolecular non-covalent architecture (31-33). Also, low-level HHP may inactivate certain enzymes but does not cause extensive conformational changes in protein structures (34). 
We have already shown in previous studies that excessive HHP $\leq 600 \mathrm{MPa}$ damages normal and tumor cells but does not lead to any significant alteration of the biomechanical and biological properties of the bone regarding the extracellular matrix proteins fibronectin, vitronectin, and collagen-I (8). In summary, we now provide evidence that particular serine proteases and pro-MMP-9 involved in tumor bone turnover are not activated by excessive HHP. Nevertheless, after HHP treatment of $400 \mathrm{MPa}$, pro-MMP-9 is more sensitive to activation.

The presented data, and data presented in the literature regarding tumor-associated proteases encourage further exploration of the potential of HHP to sterilize tumoraffected bone segments prior to reimplantation. During HHP treatment tumor cells are irreversibly damaged, while the treatment exerts no activating effects on the proteases investigated.

\section{Acknowledgements}

This study was supported in part by the Research Network for Tissue Engineering and Rapid Prototyping (Forschungsverbund FORTEPRO, project TE3) of the Bavarian Research Foundation (Bayerische Forschungsstiftung).

\section{References}

1. Diehl P, Schmitt M, Blumelhuber G, Frey B, van Laak S, Fischer S, Muehlenweg B, Meyer-Pittroff R, Gollwitzer H and Mittelmeier W: Induction of tumor cell death by high hydrostatic pressure as a novel supporting technique in orthopedic surgery. Oncol Rep 10: 1851-1855, 2003.

2. Diehl P, Reuning U, Gollwitzer H, Magdolen U, Gerdesmeyer L, Schauwecker J, Tuebel J, Gradinger R, Mittelmeier W and Schmitt M: Effect of extracorporeal high hydrostatic pressure on tumor cell adherence and viability. Oncol Rep 12: 369-373, 2004.

3. Naal FD, Mengele K, Schauwecker J, Gollwitzer H, Gerdesmeyer L, Reuning U, Mittelmeier W, Gradinger R, Schmitt M and Diehl P: High hydrostatic pressure-induced cell death in human chondrocytes and chondrosarcoma cells. Anticancer Res 25: 1977-1982, 2005.

4. Schauwecker J, Wirthmann L, Schmitt M, Tuebel J, Magdolen U, Gradinger R, Mittelmeier W and Diehl P: Effect of extracorporeal high hydrostatic pressure on cellular outgrowth from tumor-afflicted bone. Anticancer Res 26: 85-89, 2006.

5. Diehl P, Steinhauser E, Gollwitzer H, Heister C, Schauwecker J, Milz S, Mittelmeier W and Schmitt M: Biomechanical and immunohistochemical analysis of high hydrostatic pressuretreated Achilles tendons. J Orthop Sci 11: 380-385, 2006.

6. Diehl P, Naal FD, Schauwecker J, Steinhauser E, Milz S, Gollwitzer H and Mittelmeier W: Biomechanical properties of articular cartilage after high hydrostatic pressure treatment. Biomed Tech 51: 8-14, 2006.

7. Steinhauser E, Diehl P, Hadaller M, Schauwecker J, Busch R, Gradinger R and Mittelmeier W: Biomechanical investigation of the effect of high hydrostatic pressure treatment on the mechanical properties of human bone. J Biomed Mater Res B Appl Biomater 76: 130-135, 2006.

8. Diehl P, Schmitt M, Schauwecker J, Eichelberg K, Gollwitzer H, Gradinger R, Goebel M, Preissner KT, Mittelmeier W and Magdolen U: Effect of high hydrostatic pressure on biological properties of extracellular bone matrix proteins. Int J Mol Med 16: $285-289,2005$

9. Fisher JL, Mackie PS, Howard ML, Zhou H and Choong PF: The expression of the urokinase plasminogen activator system in metastatic murine osteosarcoma: an in vivo mouse model. Clin Cancer Res 7: 1654-1660, 2001.

10. $\mathrm{Vu} \mathrm{TH}$ and Werb Z: Matrix metalloproteinases: effectors of development and normal physiology. Genes Dev 14: 2123-2133, 2000.
11. Wilhelm S, Wilhelm O, Schmitt M and Graeff H: Inactivation of receptor-bound pro-urokinase-type plasminogen activator (pro-uPA) by thrombin and thrombin/thrombomodulin complex. Biol Chem Hoppe Seyler 375: 603-608, 1994.

12. Delaisse JM, Engsig MT, Everts V, del Carmen OM, Ferreras M, Lund L, Vu TH, Werb Z, Winding B, Lochter A, Karsdal MA, Troen T, Kirkegaard T, Lenhard T, Heegaard AM, Neff L, Baron R and Foged NT: Proteinases in bone resorption: obvious and less obvious roles. Clin Chim Acta 291: 223-234, 2000.

13. Himelstein BP, Asada N, Carlton MR and Collins MH: Matrix metalloproteinase-9 (MMP-9) expression in childhood osseous osteosarcoma. Med Pediatr Oncol 31: 471-474, 1998

14. Peng TS, Qiu JS, Wu HX, Liang HZ and Luo CQ: Expressions of CD44s, MMP-9, and Ki-67: possible association with invasion, metastasis, and recurrence of osteosarcoma. Ai Zheng 21: 745-750, 2002.

15. Vliagoftis $\mathrm{H}$ : Thrombin induces mast cell adhesion to fibronectin: evidence for involvement of protease-activated receptor-1. J Immunol 169: 4551-4558, 2002.

16. Verheijen JH, Nieuwenbroek NM, Beekman B, Hanemaaijer R, Verspaget HW, Ronday HK and Bakker AH: Modified proenzymes as artificial substrates for proteolytic enzymes: colorimetric assay of bacterial collagenase and matrix metalloproteinase activity using modified pro-urokinase. Biochem $\mathbf{J}$ 323: 603-609, 1997.

17. Deutscher MP: Maintaining protein stability. Methods Enzymol 182: 83-89, 1990.

18. Yao PM, Buhler JM, d'Ortho MP, Lebargy F, Delclaux C, Harf A and Lafuma C: Expression of matrix metalloproteinase gelatinases $\mathrm{A}$ and $\mathrm{B}$ by cultured epithelial cells from human bronchial explants. J Biol Chem 271: 15580-15589, 1996.

19. Araki N, Myoui A, Kuratsu S, Hashimoto N, Inoue T, Kudawara I, Ueda T, Yoshikawa H, Masaki N and Uchida A: Intraoperative extracorporeal autogenous irradiated bone grafts in tumor surgery. Clin Orthop 196-206, 1999.

20. Asada N, Tsuchiya H, Kitaoka K, Mori Y and Tomita K: Massive autoclaved allografts and autografts for limb salvage surgery. A 1-8 year follow-up of 23 patients. Acta Orthop Scand 68: 392-395, 1997.

21. Böhm P, Springfeld R and Springer H: Re-implantation of autoclaved bone segments in musculoskeletal tumor surgery. Clinical experience in 9 patients followed for 1.1-8.4 years and review of the literature. Arch Orthop Trauma Surg 118: 57-65, 1998.

22. Böhm P, Fritz J, Thiede S and Budach W: Reimplantation of extracorporeal irradiated bone segments in musculoskeletal tumor surgery: clinical experience in eight patients and review of the literature. Langenbecks Arch Surg 387: 355-365, 2003.

23. Chen WM, Chen TH, Huang CK, Chiang CC and Lo WH: Treatment of malignant bone tumours by extracorporeally irradiated autograft-prosthetic composite arthroplasty. J Bone Joint Surg Br 84: 1156-1161, 2002.

24. Knaepler H, Ascherl R, von Garrel T and Gotzen L: Guidelines for allogeneic bone transplantation. Chirurg 62: 763-765, 1991.

25. Hill PA, Docherty AJ, Bottomley KM, O'Connell JP, Morphy JR, Reynolds JJ and Meikle MC: Inhibition of bone resorption in vitro by selective inhibitors of gelatinase and collagenase. Biochem J 308: 167-175, 1995.

26. Tumber A, Papaioannou S, Breckon J, Meikle MC, Reynolds JJ and Hill PA: The effects of serine proteinase inhibitors on bone resorption in vitro. J Endocrinol 178: 437-447, 2003.

27. Jung S, Lamballerie-Anton M, Taylor RG and Ghoul M: Highpressure effects on lysosome integrity and lysosomal enzyme activity in bovine muscle. J Agric Food Chem 48: 2467-2471, 2000.

28. Lima LM, Zingali RB, Foguel D and Monteiro RQ: New insights into conformational and functional stability of human alpha-thrombin probed by high hydrostatic pressure. Eur J Biochem 271: 3580-3587, 2004.

29. Ruan K, Lange R, Bec N and Balny C: A stable partly denatured state of trypsin induced by high hydrostatic pressure. Biochem Biophys Res Commun 239: 150-154, 1997.

30. Homma N, Ikeuchi Y and Suzuki A: Effects of high-pressure treatment on the proteolytic-enzymes in meat. Meat Sci 38: 219-228, 1994.

31. Boonyaratanakornkit BB, Park CB and Clark DS: Pressure effects on intra- and intermolecular interactions within proteins. Biochim Biophys Acta 1595: 235-249, 2002. 
32. Mozhaev VV, Lange R, Kudryashova EV and Balny C: Application of high hydrostatic pressure for increasing activity and stability of enzymes. Biotechnol and Bioeng 52: 320-331, 1996.

33. Perrett $S$ and Zhou JM: Expanding the pressure technique: insights into protein folding from combined use of pressure and chemical denaturants. Biochim Biophys Acta 1595: 210-223, 2002.
34. Masson P, Tonello C and Balny C: High-pressure biotechnology in medicine and pharmaceutical science. J Biomed Biotechnol 1: 85-88, 2001.

35. Balny C, Masson $\mathrm{P}$ and Heremans K: High pressure effects on biological macromolecules: from structural changes to alteration of cellular processes. Biochim Biophys Acta 1595: 3-10, 2002. 